\title{
OPEN The ecological importance of habitat complexity to the Caribbean coral reef herbivore Diadema antillarum: three lines of evidence
}

\author{
M. D. V. Bodmer ${ }^{1,2,3 凶}$, P. M. Wheeler ${ }^{2}$, P. Anand ${ }^{2}$, S. E. Cameron ${ }^{1,2}$, Sanni Hintikka ${ }^{4}$, \\ W. Cai ${ }^{1,5}$, A. O. Borcsok ${ }^{6} \&$ D. A. Exton ${ }^{1}$
}

When Caribbean long-spined sea urchins, Diadema antillarum, are stable at high population densities, their grazing facilitates scleractinian coral dominance. Today, populations remain suppressed after a mass mortality in 1983-1984 caused a loss of their ecosystem functions, and led to widespread declines in ecosystem health. This study provides three lines of evidence to support the assertion that a lack of habitat complexity on Caribbean coral reefs contributes to their recovery failure. Firstly, we extracted fractal dimension (D) measurements, used as a proxy for habitat complexity, from 3D models to demonstrate that urchins preferentially inhabit areas of above average complexity at ecologically relevant spatial scales. Secondly, controlled behaviour experiments showed that an energetically expensive predator avoidance behaviour is reduced by $52 \%$ in complex habitats, potentially enabling increased resource allocation to reproduction. Thirdly, we deployed a network of simple and cost-effective artificial structures on a heavily degraded reef system in Honduras. Over a 24-month period the adult $D$. antillarum population around the artificial reefs increased by $320 \%$ from $0.05 \pm 0.01$ to $0.21 \pm 0.04 \mathrm{~m}^{-2}$ and the juvenile $D$. antillarum population increased by $750 \%$ from $0.08 \pm 0.02$ to $0.68 \pm 0.07 \mathrm{~m}^{-2}$. This study emphasises the important role of habitat structure in the ecology of $D$. antillarum and as a barrier to its widespread recovery.

Coral reefs are among the most valuable and vulnerable ecosystems on the planet ${ }^{1,2}$. Loss of herbivory, largely driven by disease and the widespread unsustainable harvesting of fish and echinoids in small-scale fisheries ${ }^{3,4}$, has many negative impacts on coral reefs, but it is the associated macroalgae overgrowth that poses the greatest threat $^{5}$. In the absence of herbivores, structurally complex, three-dimensional hard corals are replaced by structurally simple two-dimensional macroalgae $e^{6,7}$, which reduces habitat availability and drives decreases in species richness and abundance ${ }^{8}$. Species richness begets functional redundancy and response diversity, which confers resilience ${ }^{9,10}$ and has a stabilising effect on ecosystem function ${ }^{11}$.

In comparison to the Indo-Pacific, the Caribbean has just $28 \%$ and $14 \%$ of the diversity of fishes and corals respectively ${ }^{12}$, and its reefs are consequently less resilient than other global hotspots ${ }^{13,14}$. This relative lack of diversity means that the echinoid herbivore, Diadema antillarum, is historically considered among the most important macroalgae grazers in the Caribbean ${ }^{15-17}$, and its relative importance likely increased since mass overfishing reduced abundances of key herbivorous fish ${ }^{18}$. Numerous modelling and experimental studies indicate that D. antillarum ecosystem functions are activated at densities of $0.6-1.0$ individuals $\mathrm{m}^{-2} 19-21$, and high-density populations can consume the entire daily growth of macroalgae ${ }^{22}$. The negative correlation between $D$. antillarum population density and macroalgae cover is well documented ${ }^{23}$ and is closely associated with a positive correlation between echinoid density and hard coral cover ${ }^{15,24-28}$.

\footnotetext{
${ }^{1}$ Operation Wallacea, Wallace House, Old Bolingbroke, Spilsby, Lincolnshire PE23 4EX, UK. ${ }^{2}$ School of Environment, Earth and Ecosystem Sciences, The Open University, Walton Hall, Milton Keynes MK7 6AA, UK. ${ }^{3}$ School of Life Sciences, College of Science, University of Lincoln, Brayford Way, Lincoln LN6 7TS, UK. ${ }^{4}$ University College Dublin, Belfield, Brayford Way, Dublin 4, Ireland. ${ }^{5}$ Department of Life Sciences, Imperial College London, London SW7 2BX, UK. ${ }^{6}$ Tela Marine Research Centre, Honduras Shores Plantation, Tela, Atlantida, Honduras. ${ }^{\varpi}$ email: mbodmer@lincoln.ac.uk; sanni.hintikka@ucdconnect.ie
} 
In the early 1980s, an unknown water-borne pathogen reduced D. antillarum populations by $95-100 \%$ as it spread throughout the Caribbean ${ }^{25,29-31}$. Historical records of D. antillarum population densities are inconsistent, but the impacts of, and subsequent recovery from, the disease have been well documented in Panama. Here, densities were reduced from an average of $3.5 \mathrm{~m}^{-2}{ }^{32}$, to $0.0001 \mathrm{~m}^{-2}{ }^{29}$, and two decades later populations had recovered to just $6.5 \%$ of their pre-mortality levels ${ }^{33}$. This pattern of population destruction followed by a lack of recovery has been observed across the entire extent of the region from Barbados ${ }^{34}$, Venezuela ${ }^{35}$, and Curacao ${ }^{36,37}$ in the south, to the Florida Keys ${ }^{16}$ in the north. The functional extinction of D. antillarum led to Caribbean-wide macroalgae increases of up to $50 \%{ }^{38}$ and is undoubtedly a contributing factor to the $80 \%$ coral loss observed in the Caribbean from 1970 to $2000^{39}$, and the continuing decline to an average cover of just $16.3 \%$ in $2012^{7}$.

D. antillarum restoration is a priority, but first the mechanisms by which populations are being supressed must be identified and removed ${ }^{19}$. Echinoids are density-dependent external fertilisers and reproductive success correlates with adult population density ${ }^{40,41}$. At low density, large nearest-neighbour distances reduce the probability of fertilisation success, therefore reductions in population density associated with the mass-mortality likely created an Allee effect that has prevented recovery ${ }^{42}$. This effect may be continually reinforced by a positive feedback loop that was established after the die-off; loss of $D$. antillarum ecosystem functions caused declines in structurally complex hard coral cover, which reduced the availability of their own habitat ${ }^{28}$. In turn, this increased the average nearest-neighbour distance between individuals ${ }^{40}$ and exacerbated the Allee effect ultimately driving further declines in adult population density. The negative impact of this Allee effect is likely compounded by the poor success of juvenile recruits who are unable to seek shelter in the spiny canopy of densely aggregated adults, or within the complex framework of the reef which has flattened considerably since the $1980 \mathrm{~s}^{8,43}$.

Numerous correlative studies have shown a positive relationship between $D$. antillarum population density and habitat structure. These studies have elucidated an important ecological driver of D. antillarum dynamics, and hypothesise there are two mechanisms by which complex habitats likely facilitate survival of larger populations; by increasing recruitment, and providing predation refugia that facilitate juvenile survival into adulthood ${ }^{28,44-46}$. D. antillarum reintroduction may therefore be successful, if coupled with the artificial augmentation of 3D habitat complexity, although our current understanding is based largely on correlative analyses and urgently needs to be supported by experimental evidence.

Here we extend our understanding of the importance of habitat complexity by exploring its relationship with $D$. antillarum population structure and behaviour using a more experimental approach. We present three independent lines of evidence highlighting the ecological importance of habitat complexity to the survival, distribution and recovery of $D$. antillarum on Caribbean coral reefs. First, we use structural complexity (fractal dimension) data extracted from 3D models of the underlying reef architecture to show that individuals from a low-density population are found in areas of reef with disproportionately higher habitat complexity than the background average at an ecologically relevant spatial scale. We hypothesise that the $5-15 \mathrm{~cm}$ spatial scale, $D$. antillarum exhibit a preference for higher complexity habitat because their test diameter can be up to $10 \mathrm{~cm}^{47}$, and they must also have room for their articulated spines. We then use an ex situ lab-based experiment to address the hypothesis that $D$. antillarum demonstrate behavioural changes in the presence of enhanced habitat complexity that reduce energetic requirements associated with predator avoidance and thus improve survival potential. Finally, we use our findings to justify the deployment of a network of simple and cost-effective artificial reefs, designed to provide optimal habitat complexity to both juvenile and adult $D$. antillarum, on a highly degraded reef system. Our results support the hypothesis that enhancement of reef structure can augment $D$. antillarum populations as we report significant increases in densities over a 24-month period relative to nearby control reefs.

\section{Methods}

Study sites. We investigated the importance of habitat structure to D. antillarum population dynamics using two in situ field studies and an ex -situ lab-based experiment. The in situ studies allowed us to explore the impacts of habitat structure on D. antillarum population dynamics, whilst the ex-situ study enabled elucidation of the mechanisms that may drive the relationships observed in the field.

These studies took place on the reefs of Utila and Tela Bay, at the southern end of the Mesoamerican Barrier Reef System (MBRS) in Honduras. Utila is one of the Bay Islands of Honduras located approximately $40 \mathrm{~km}$ from the mainland and it is a popular tourist destination. Tela Bay is home to a diverse range of marine ecosystems, including Banco Capiro, which has a hard coral and macroalgae cover of $62 \%$ and $7 \%$ respectively ${ }^{48}$, making it one of the healthiest reef systems in the Caribbean. In 2018, an $822.6 \mathrm{~km}^{2}$ area of the bay was afforded protection by the Honduran government as part of the El Refugio de Vida Silvestre Marino de Tela.

In situ habitat preferences of $D$. antillarum. We studied $D$. antillarum habitat complexity preferences on reefs around the island of Utila, Honduras, which is home to an extensive fringing reef system ${ }^{49}$. With mean scleractinian coral cover of $12-22 \%$, and D. antillarum populations varying from $0.17 \mathrm{~m}^{-2}$ at $2 \mathrm{~m}$ depth to just $0.01 \mathrm{~m}^{-2}$ at $10 \mathrm{~m} \mathrm{depth}{ }^{28}$, it represents a 'typical' contemporary Caribbean reef with little to no post-mortality recovery of D. antillarum ${ }^{50}$.

Habitat complexity was measured within $2 \times 2 \mathrm{~m}$ quadrats placed randomly on six reef sites along the south shore of the island at depths of 8-10 m. The presence/absence of $D$. antillarum was recorded in each quadrat; 35 quadrats without urchins were assessed and a further five urchin-containing-quadrats were sampled to allow complexity differences to be elucidated. The uneven sample sizes, a result of the dearth of $D$. antillarum on study reefs, were accounted for in the statistical analyses.

Collection and production of 3D models. Advancements in 3D modelling technologies have enabled researchers to move away from outdated and inaccurate methodologies used for assessing habitat complexity, e.g. Risk's 
chain method for quantifying rugosity ${ }^{51}$. Habitat complexity measurements, in the form of fractal dimension (D), can be extracted from 3D models at different spatial scales, allowing researchers to gain a better understanding of the importance of 3D architecture to their study organism.

Underwater photogrammetry using structure-from-motion is now a well-established approach used to quantify complexity on coral reefs ${ }^{52-55}$. Here, we followed an existing method for footage collection, model construction and analysis ${ }^{55}$. In summary, 3D models were built based on video scans of the quadrats, filmed from a birds-eye perspective with a single camera (GoPro Hero 4 Black) held approximately $50 \mathrm{~cm}$ above the substrate. The quadrat was swept in a lawnmower pattern, ensuring a minimum overlap of $25 \mathrm{~cm}$ between passes; essential for successful image alignment and model construction. Each video was approximately 3 min long.

Videos were converted to still images using QuickTime Player v.7.6.6 (QuickTime 1989-2010) at an extraction rate of 3 frames per second which generated 450 to 540 still images per quadrat. These images were uploaded to PhotoScan Pro v.1.3.2 (Agisoft PhotoScan Professional 2017) and 3D models constructed. Resultant PhotoScan files (.psx) were converted to object files (.obj) and imported into Rhinoceros 3D 5.3.2 (Rhinoceros 1993-2017) for analysis.

Quantifying habitat complexity using fractal dimension. We quantified habitat complexity using fractal dimension (D), which measures how complexity changes between two defined resolutions ${ }^{56}$, making it ideal when focusing on a single study organism as it allows complexity which is ecologically relevant to that species to be quantified in isolation. It returns a value between 2 and 3, with a higher number indicating greater complexity, and was calculated using a published Python script $t^{55}$.

D. antillarum have fully articulated spines ${ }^{57}$ therefore their ability to fit into a crevice is determined by their test diameter. Crevices in the reef provide echinoids with predation refugia ${ }^{16}$ but only if the gap between their test and sides of the crevice prevents predators from entering. To identify spatial scales that are ecologically relevant to local $D$. antillarum populations with regards to predator avoidance, we measured the test diameter of adult $D$. antillarum at our two study locations in Utila $(n=139)$ and Tela Bay $(n=100)$. Using SCUBA, we searched the reef for adult urchins and coerced them from their crevice using a $50 \mathrm{~cm}$ length of PVC pipe. The test diameter, excluding spines, of each individual was measured using a long-jaw calliper.

To assess variation in D. antillarum structural preferences at different spatial scales, we calculated $\mathrm{D}$ at the following resolutions: $1-5 \mathrm{~cm}, 5-15 \mathrm{~cm}, 30-60 \mathrm{~cm}$ and $60-120 \mathrm{~cm}$. Test diameter measurements in Utila revealed that the $5-15 \mathrm{~cm}$ resolution was likely to be the most relevant to local $D$. antillarum because adult test diameters ranged from 21 to $90 \mathrm{~mm}$. D. antillarum spines often measure $>30 \mathrm{~cm}$ but they are highly articulated, therefore an individual's ability to occupy a crevice is determined by its width when the spines are folded over the test ${ }^{57}$; an individual with a test diameter of $21 \mathrm{~mm}$ will likely need a $>50 \mathrm{~mm}$ crevice and an individual with a test diameter of $90 \mathrm{~mm}$ will likely need a $>120 \mathrm{~mm}$ crevice. The five size categories were ultimately used to plot complexity signatures, providing a visual representation of how complexity changes across spatial scales between reef areas with and without urchins. This approach has recently been used successfully to demonstrate size-specific habitat associations of invasive Caribbean lionfish ${ }^{58}$.

Ex situ impacts of structural complexity on $D$. antillarum predator avoidance behaviour (PAB). The in situ habitat structure preference study elucidated that $D$. antillarum prefer complex habitats at the 5-15 cm spatial scale. We therefore conducted an ex situ lab-based study to try and identify the mechanisms that may drive this relationship.

D. antillarum predator avoidance behaviour $(\mathrm{PAB})$ is defined as the number of long-defensive spines that move in response to a predatory threat, e.g. a shadow stimulus ${ }^{48,59-62}$. Decreased light intensity may signal the presence of a predator, and it causes the expansion of melanophores in the dermis, which induces a nervous signal that stimulates spine movement thus decreasing the efficacy of a predatory attack ${ }^{63}$. Bodmer et al. ${ }^{48}$ found that $\mathrm{PAB}$ of individuals collected from architecturally complex reefs was lower than those collected from structurally simple reefs. They suggested that complex habitats, by offering natural protection against predation, allow individuals to gain energetic benefits from reducing their reliance on $\mathrm{PAB}^{59,60}$. Here, we use the same approach as Bodmer et al. ${ }^{48}$ but go further by introducing varying levels of habitat structure into the experimental setup.

Setup of the trial tanks. PAB was measured under three different complexity treatments by enriching trial tanks with either natural or artificial reef material. For 'flat' treatments no reef material was added to the tanks. For the 'natural' treatments, trial tanks were enriched with rubble collected from the reef; low-complexity-naturalmaterial assays involved placing a single layer of reef rubble over the bottom of the tank, and high-complexitynatural-material assays were built off this low-complexity foundation, but were enhanced by the addition of 'walls' and a 'roof' in order to simulate a natural D. antillarum reef crevice (Fig. 1). During 'artificial' treatments, D. antillarum were provided with habitats made from concrete; low-complexity-artificial-material assays were created by breaking up a breezeblock and lining the bottom of the tank with the fragments, high-complexityartificial assays involved placing a whole breezeblock in the tank (Fig. 1).

The location of the reef material in the tanks was assigned prior to each trial using a random number generator to control for the position effect. 50 black adult urchins were tested under 5 different experimental treatment combinations in a fully factorial design ( $\mathrm{n}=10$ for each combination). Each urchin was used for a single trial only.

Each trial was carried out in one of three $300 \mathrm{~L}$ tanks containing fresh seawater which was replaced daily. Aquarium heaters (Aquael Easy Submersible Aquarium Heater 150w) were used to maintain trial tanks at $29.7 \pm 0.3^{\circ} \mathrm{C}$. This control temperature was selected because throughout the trial period (May to August 2016) temperatures in the study area (longitude $=15.879404$; latitude $=-87.515967$ ) ranged from 28.58 to $31.68{ }^{\circ} \mathrm{C}$ and the mean SST was $29.87^{\circ} \mathrm{C}$ (daily mean $\left.\mathrm{SD}= \pm 0.71^{\circ} \mathrm{C}\right)^{64}$. Six trials were completed daily and the treatment 


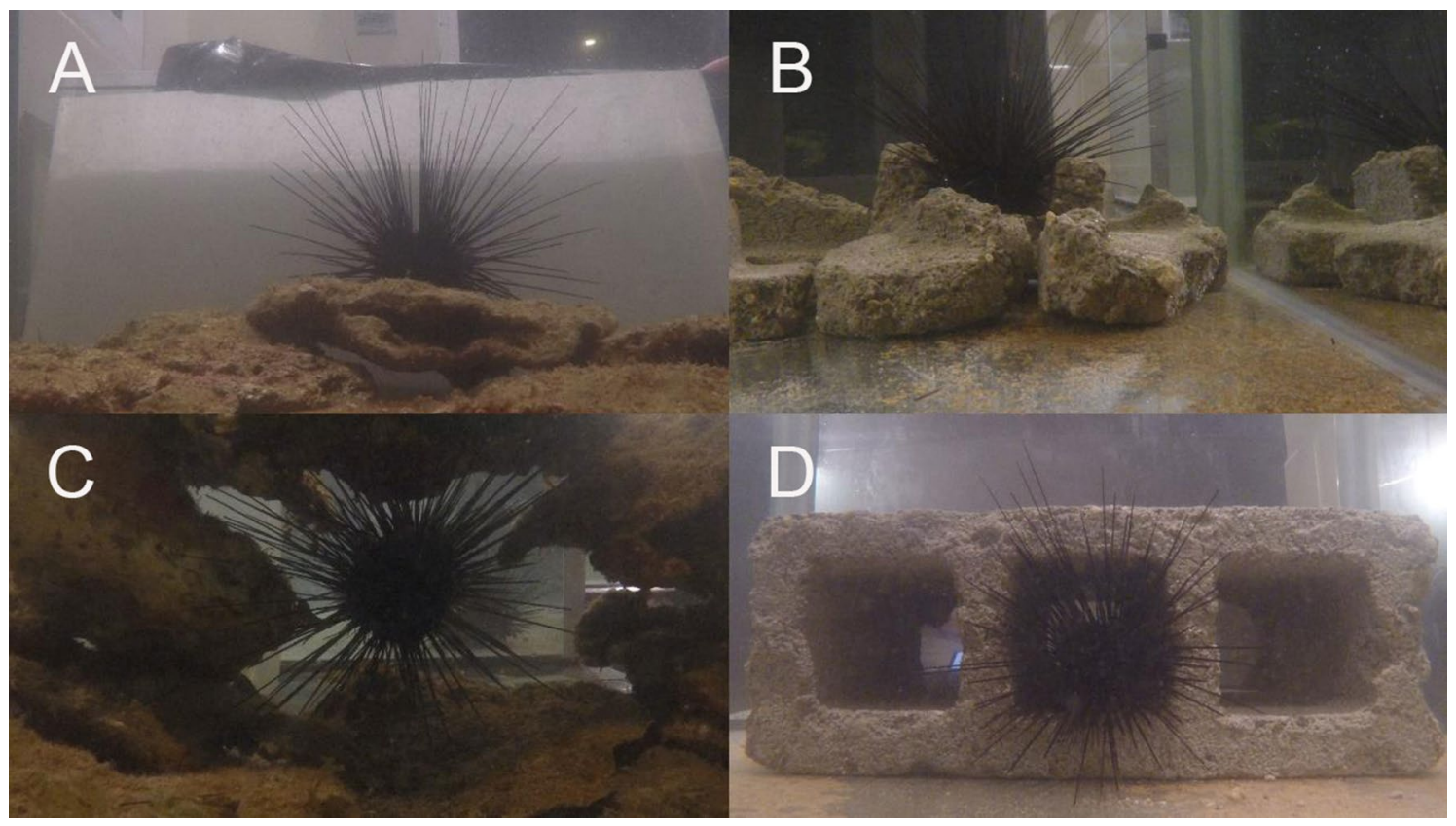

Figure 1. Panel photograph showing tank setup for different complexity treatments. Top left natural-materiallow-complexity, top right = artificial-material-low-complexity, bottom left = natural-material-high-complexity, bottom right $=$ artificial-material-high-complexity.

combination in any given tank was randomised along with the treatment order to control for potentially confounding variables.

Collection of urchins. Urchins were collected from Banco Capiro, a large offshore reef system found ca. $8 \mathrm{~km}$ from the coast in Tela Bay, Honduras. With a mean hard coral cover of $62 \%$ at $10 \mathrm{~m}$, and associated D. antillarum population densities of $2.6 \mathrm{~m}^{-2} 28$, Banco Capiro may be one of the healthiest reefs found in the Caribbean today. Individuals were removed from the reef using a $50 \mathrm{~cm}$ length of PVC piping. Six specimens were collected each day, retained for a maximum of $24 \mathrm{~h}$ and returned to the site of their collection the following morning. Pseudoreplication was avoided by returning urchins to a different sub-site of the reef from where new specimens were collected. Prior to commencement of trials urchins were placed in $300 \mathrm{~L}$ glass holding tanks maintained at ambient SST in the laboratory for at least eight hours. Conservation of D. antillarum is a priority throughout the Caribbean, and so short acclimatisation periods were used to minimise the risk of mortality caused by experimentally induced stress.

Trial protocol and data generation. For each trial an individual D. antillarum was placed in the trial tank and allowed to settle for $30 \mathrm{~min}$. Urchins naturally seek shelter, therefore, in treatments where it was available, they quickly moved towards the structure in the tank. After the settling period, a GoPro Hero 4 was set to record, placed in the tank and positioned to focus on the urchin.

Presence of a predator was simulated by creating a shadow over the tank ${ }^{48}$. Predator avoidance behaviour (PAB) was defined as the number of spines that move in response to the shadow stimulus as a percentage of the total number of long defensive spines visible in the video. This effectively standardises the measure between urchins and negates the problem that some long spines may be obscured by structures in the tank. Videos were analysed in a random order to avoid observer bias.

Impacts of artificially augmenting habitat structure on $D$. antillarum population density. The results of the first two studies indicated that $D$. antillarum may prefer complex habitats because they provide predation refugia. We therefore deployed a network of artificial reefs (ARs) at La Ensenada, a shallow patch reef (3-10 $\mathrm{m}$ depth) located in Tela Bay, to see if augmentation of habitat structure could promote population recovery, and to assess the validity of ARs as a population restoration strategy. Initial diver observations indicated that La Ensenada is a degraded system with hard coral cover well below $10 \%$, macroalgae cover up to $60 \%$, and D. antillarum population densities significantly less than the $1 \mathrm{~m}^{-2}$ required for their ecosystem functions to be activated ${ }^{20}$.

Artificial reef design and deployment. In summer 2015, 30 experimental ARs were deployed, each constructed from 16 locally manufactured breezeblocks/cinder blocks (external dimensions: $41 \times 20 \times 20 \mathrm{~cm}$ ) incorporating three holes of $10 \times 10 \mathrm{~cm}$ diameter. Breezeblocks with these dimensions were chosen since (i) many AR initiatives fail because of high costs ${ }^{65}$, (ii) concrete has been identified as a suitable AR material ${ }^{19,66}$, (iii) they were readily available locally, (iv) our ex-situ PAB study demonstrated no effect of artificial (concrete) versus natural 


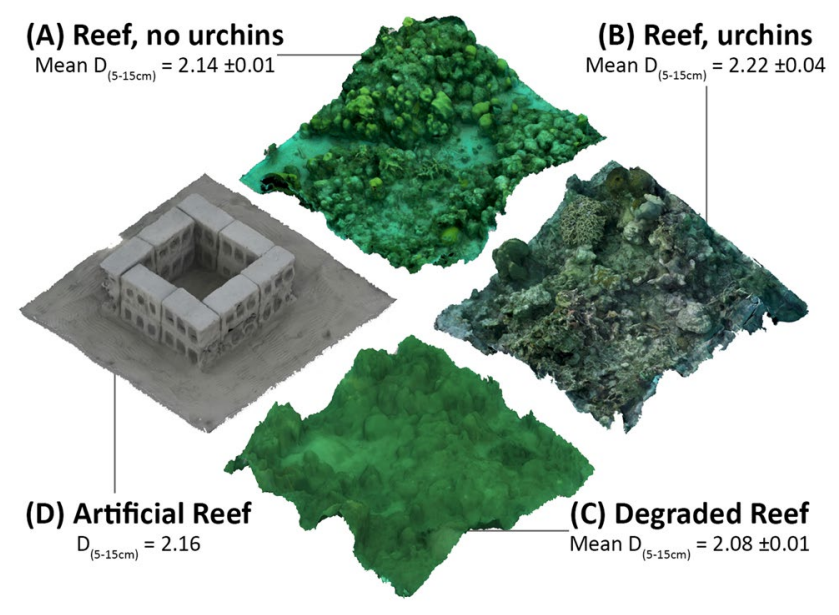

Figure 2. Three-dimensional images showing complexity differences between: (A) a $2 \mathrm{~m} \times 2 \mathrm{~m}$ area of reef without urchins on Utila, (B) a $2 \mathrm{~m} \times 2 \mathrm{~m}$ area of reef with urchins on Utila, (C) a $2 \mathrm{~m} \times 2 \mathrm{~m}$ area of control reef in La Ensenada, (D) an artificial reef deployed at La Ensenada. $D_{(5-15 \mathrm{~cm})}=$ fractal dimension of the model at the $5-15 \mathrm{~cm}$ spatial resolution. Mean \pm 1 SE is reported for $(\mathbf{A})-(\mathbf{C})$, but all artificial reefs are identical therefore variation in fractal dimension for $(\mathrm{D})$ is not reported.

structure on urchin behaviour (see "Results" section) and (v) our survey of $D$. antillarum test diameters in Tela Bay suggested $10 \times 10 \mathrm{~cm}$ diameter holes would provide suitable refugia for individuals at the lower end of the test size range (i.e. likely new recruits to our artificial reefs).

Ten ARs were constructed at each of three sub-sites; Palm View 1 (N 15.80337 W 087.43922), Palm View 2 (N 15.80336 W 8743955), and Becky's Choice (N 15.80494 W 87.43955). ARs were separated by a minimum distance of $30 \mathrm{~m}$, with lift bags used to safely lower materials from a support boat to the seafloor. Once all blocks had been lowered, the SCUBA team constructed the AR by creating a two-layered square structure on the benthos with holes facing outwards/inwards (Fig. 2).

Assessing population recovery. D. antillarum population assessments and benthic surveys were carried out around each AR immediately after deployment (summer 2015), after 12 months (summer 2016) and after 24 months (summer 2017). In each survey period, data were collected from ten $1 \mathrm{~m}^{2}$ quadrats that were randomly placed within a $5 \mathrm{~m}$ radius of the centre of the AR. In each quadrat, the abundance of $D$. antillarum was recorded along with the life-history stage of all individuals that were encountered; juveniles are identifiable by distinctive black and white striped spines ${ }^{57}$. Quadrats were also photographed and analysed for juvenile coral recruits, defined here as coral colonies $<40 \mathrm{~mm}$ in their longest dimension ${ }^{23}$, and for percentage cover of macroalgae using CoralPointCount (CPCe) software with 100 points randomly overlaid on each image. Percentage cover of mature scleractinian coral was not examined due to the relatively short ( 24 month) timeframe of this project meaning genuine changes were unlikely to be reliably detectable.

Control data were collected following Bodmer et al. ${ }^{28}$ to ensure that any observed inter-year differences were associated with AR deployment and not natural changes in the system. Randomly placed $50 \times 2 \mathrm{~m}$ belt transects created a $100 \mathrm{~m}^{2}$ survey area in which $D$. antillarum and juvenile coral recruit abundances were recorded. Benthic percentage cover was calculated using point-intercept video transects analysed at $0.25 \mathrm{~m}$ intervals. Two transects were carried out on control reefs located at least $100 \mathrm{~m}$ away from any of the ARs at each sub-site $(\mathrm{n}=6)$.

The methods used to assess the relative changes around the artificial and control reefs differed. Transects allowed us to survey a large area of the control reef to gain an accurate understanding of the background patterns of change, but they were not appropriate for assessing localised changes within $5 \mathrm{~m}$ of the AR structures. As a result, these data are not directly compared statistically.

Statistical methods. All analyses were conducted using R v. 3.3.167 and RStudio v0.99.903 ${ }^{68}$.

Assessing in situ habitat preferences. The first part of this study used fractal dimension (D) as a proxy for structural complexity to explore the in-situ habitat preferences of $D$. antillarum. We assessed differences in $D$ between quadrats inhabited by $D$. antillarum to those without, using Mann-Whitney $\mathrm{U}$ tests, which are robust to unbalanced survey designs. We conducted one test for each of the five spatial resolutions $(1-5 \mathrm{~cm}, 5-15 \mathrm{~cm}, 30-60 \mathrm{~cm}$ and $60-120 \mathrm{~cm}$ ), and adjusted the results for multiple comparisons using the Bonferroni method.

Assessing impacts of structure on D. antillarum predator avoidance behaviour (PAB). Predator avoidance behaviour was evaluated as a function of reef complexity (flat, low, and high), and reef material (natural and artificial), and their interaction using a two-way analysis of covariance (ANCOVA). Post-hoc Tukey-Kramer analyses were used to assess pairwise differences in $\mathrm{PAB}$ among treatment combinations. Visual analysis of the residuals 


\begin{tabular}{|l|l|l|l|}
\hline Reef type & Model & $\boldsymbol{W}$ & $\boldsymbol{p}$ \\
\hline Artificial reef & Urchins_Adult $\sim$ Year & 0.71 & $<0.05$ \\
\hline Artificial reef & Urchins_Juvenile $\sim$ Year & 0.58 & $<0.05$ \\
\hline Artificial reef & Urchins_Total $\sim$ Year & 0.66 & $<0.05$ \\
\hline Artificial reef & Coral_Recruits $\sim$ Year & 0.72 & $<0.05$ \\
\hline Artificial reef & Macroalgae $~$ Year & 0.99 & $<0.05$ \\
\hline Control reef & Urchins_Adult $\sim$ Year & 0.88 & $<0.05$ \\
\hline Control reef & Urchins_Juvenile $~$ Year & 0.83 & $<0.05$ \\
\hline Control reef & Urchins_Total $~$ Year & 0.96 & 0.60 \\
\hline Control reef & Coral_Recruits $\sim$ Year & 0.96 & 0.61 \\
\hline Control reef & Macroalgae $~$ Year & 0.93 & 0.20 \\
\hline
\end{tabular}

Table 1. Data were separated by reef type (artificial or control) and analysis of the residuals of each ecological variable by year was conducted using a Shapiro-Wilk test for normality. The residuals for most models were non-normally distributed, therefore a non-parametric approach was selected.

\begin{tabular}{|l|l|l|}
\hline Reef type & Predictor & Response variable \\
\hline Control reef & Year $(2015,2016,2017)$ & Juvenile D. antillarum abundance $\mathrm{m}^{-2}$ \\
\hline Control reef & Year $(2015,2016,2017)$ & Adult D. antillarum abundance $\mathrm{m}^{-2}$ \\
\hline Control reef & Year $(2015,2016,2017)$ & Total D. antillarum abundance $\mathrm{m}^{-2}$ \\
\hline Control reef & Year $(2015,2016,2017)$ & Juvenile coral recruit abundance $\mathrm{m}^{-2}$ \\
\hline Control reef & Year $(2015,2016,2017)$ & Macroalgae cover $(\%)$ \\
\hline Artificial reef & Year $(2015,2016,2017)$ & Juvenile D. antillarum abundance $\mathrm{m}^{-2}$ \\
\hline Artificial reef & Year $(2015,2016,2017)$ & Adult D. antillarum abundance $\mathrm{m}^{-2}$ \\
\hline Artificial reef & Year $(2015,2016,2017)$ & Total $D$. antillarum abundance $\mathrm{m}^{-2}$ \\
\hline Artificial reef & Year $(2015,2016,2017)$ & Juvenile coral recruit abundance $\mathrm{m}^{-2}$ \\
\hline Artificial reef & Year $(2015,2016,2017)$ & Macroalgae cover $(\%)$ \\
\hline
\end{tabular}

Table 2. Ten Friedman tests were used to assess changes in juvenile, adult, and total D. antillarum population density, juvenile coral recruit abundance, and macroalgae cover over a three-year period. Changes in the value of each variable were assessed independently, and separate analyses were conducted for the control and artificial reefs.

revealed that there were no influential outliers, the data were independent and normally distributed, and there was homogeneity in the variance, therefore parametric analyses were considered appropriate for these data.

Assessing the impacts of artificial reefs on D. antillarum population density and benthic composition. Changes in adult and juvenile $D$. antillarum population density within a $5 \mathrm{~m}$ radius of artificial reefs and on control reefs were assessed over a 3-year period $(2015,2016,2017)$. Inter-year comparisons of juvenile coral recruit abundance, and macroalgae cover were also made. Separate analyses were conducted for each of these ecological variables, and analyses were also separated by reef type to account for differences in the way the data were collected on control reefs and around the artificial reefs. Shapiro-Wilk tests conducted on the residuals of each ecological variable by year revealed a non-normal distribution in most cases (Table 1), therefore we used nonparametric analyses. A series of ten Friedman tests, designed for use on datasets with one-way repeated measure designs, were used to assess changes in D. antillarum population density (adult, juvenile, and total), coral recruit abundance, and macroalgae cover between 2015, 2016 and 2017 (Table 2). Post-hoc Conover Iman tests ${ }^{69}$ were used to elucidate where observed differences were found; these were adjusted using the Bonferroni correction to account for the multiple pairwise comparisons.

\section{Results}

D. antillarum test diameters. In total, 239 individual adult $D$. antillarum were collected from the reefs around Utila $(n=139)$ and Tela Bay $(n=100)$, and their test diameters were measured. At Utila, the mean test diameter was $53.52 \pm 1.20 \mathrm{~mm}($ mean $\pm 1 \mathrm{SE})$ and the range was 21 to $90 \mathrm{~mm}$. In Tela Bay, the mean was $49.69 \pm 0.65 \mathrm{~mm}$ and the range was 32 to $64 \mathrm{~mm}$ (Fig. 3). The overall mean for both locations combined was $51.92 \pm 0.76 \mathrm{~mm}$. From this value it was inferred that the $5-15 \mathrm{~cm}$ spatial scale was the most ecologically relevant to $D$. antillarum based on need for the crevice to protect the test whilst providing additional space required for the articulated spines.

In situ habitat preferences of $D$. antillarum. The habitat complexity (D) of areas inhabited by D. antillarum was compared to the mean complexity of uninhabited quadrats across five spatial scales; the only signifi- 


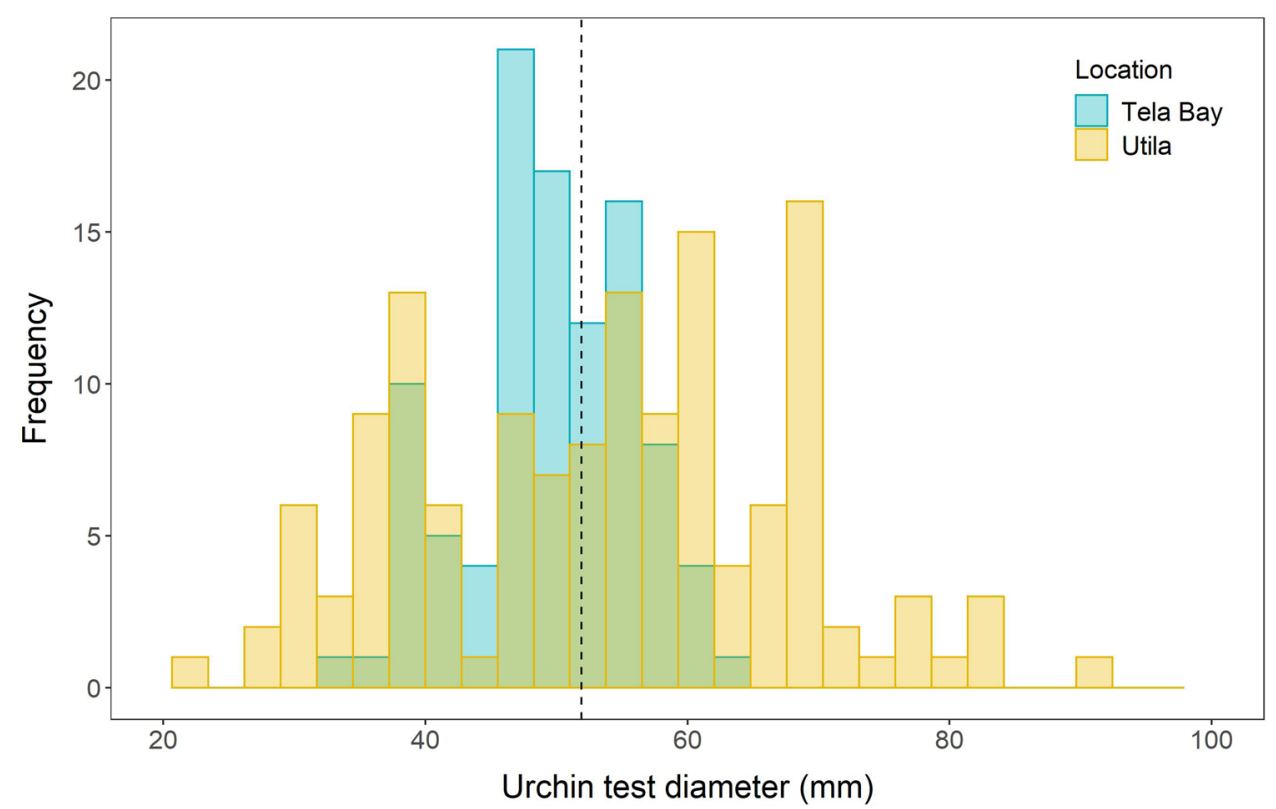

Figure 3. Distribution of adult $D$. antillarum test diameters on the reefs of Utila (yellow; $n=139$ ) and Tela (blue; $n=100)$. Dotted vertical line is the mean of all individuals from both locations.

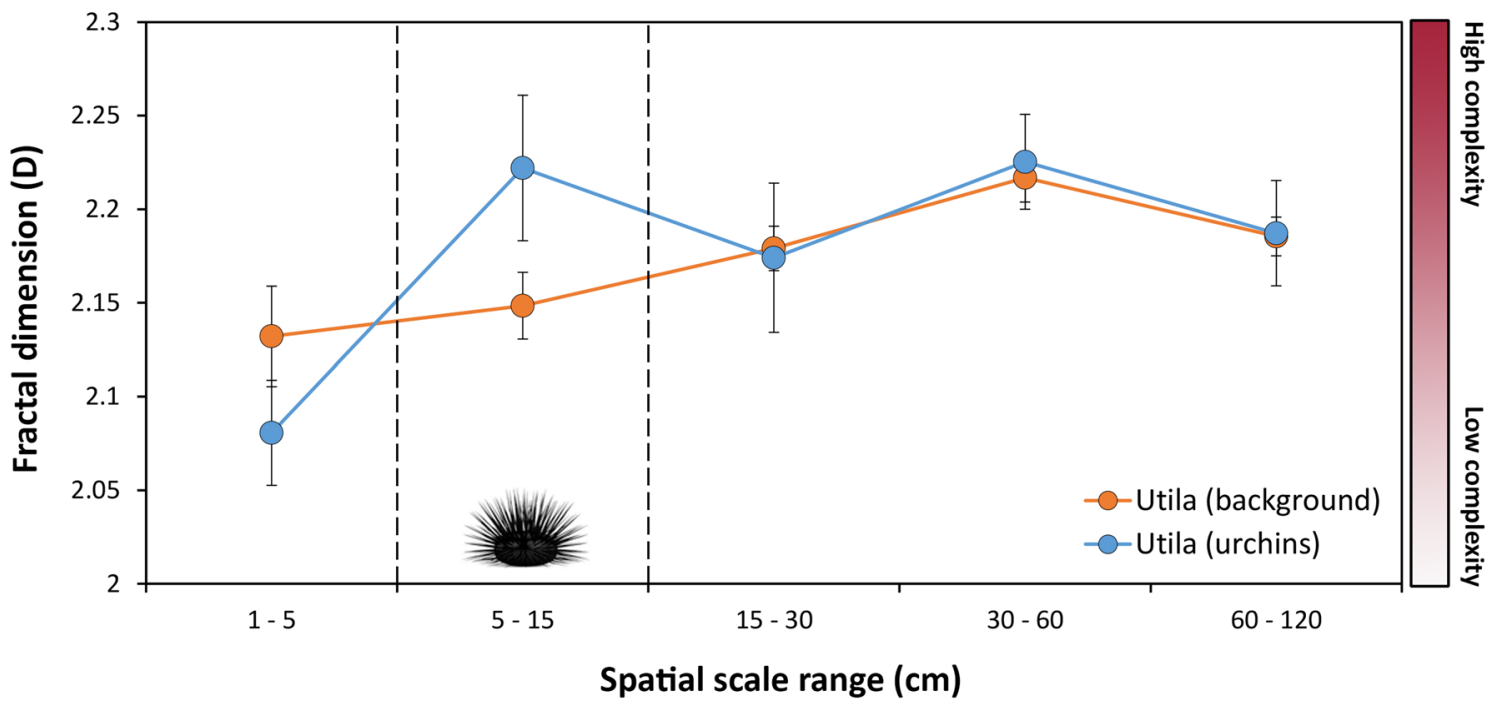

Figure 4. Complexity signatures of reef areas devoid of $D$. antillarum (orange, $\mathrm{n}=35$ ), and areas inhabited by D. antillarum (blue, $\mathrm{n}=5$ ). Data shown in the main panel are mean $\pm 1 \mathrm{SE}$ fractal dimension $(\mathrm{D})$, a measure of structural complexity within defined spatial resolutions, shown at: $1-5 \mathrm{~cm}, 5-15 \mathrm{~cm}, 15-30 \mathrm{~cm}, 30-60 \mathrm{~cm}$ and 60-120 cm, with 5-15 cm representing the size range of ecological significance to $D$. antillarum as predation refugia. D ranges from 2 to 3 and higher values are associated with greater structural complexity. Error bars represent \pm 1 SE from the mean.

cant difference occurred at 5-15 cm, the range identified as most ecologically relevant to D. antillarum (Fig. 4). Within this size category, Utila's reefs showed an average fractal dimension $\left(D_{5-15} \mathrm{~cm}\right)$ of $2.14 \pm 0.01$ in uninhabited areas, while $D$. antillarum were found in areas with an average of $2.22 \pm 0.04(W=38, p=0.049)$. At spatial scales $<5 \mathrm{~cm}$ and $>15 \mathrm{~cm}$, there were no differences in D between urchin-inhabited areas and urchin-uninhabited areas $(15-30 \mathrm{~cm}: W=98, p=0.61 ; 30-60 \mathrm{~cm}: W=80, p=0.86 ; 60-120 \mathrm{~cm}: W=94, p=0.73)$.

Impacts of structural complexity on predator avoidance behaviour. A two-way ANCOVA was used to assess the impact of structural complexity on the magnitude of $D$. antillarum Predator Avoidance behaviour, and it showed that the interaction between material and complexity was non-significant $\left(F_{1,45}=0.69\right.$, $p=0.41)$. The resultant two-way ANOVA found that both complexity $\left(F_{1,45}=62.26, p=4.98^{-10}\right)$ and material 


\begin{tabular}{|l|l|l|l|}
\hline Complexity & Material & PAB (\%) & Tukey-Kramer designation \\
\hline Flat & Glass & $54.84 \pm 7.64$ & a \\
\hline Low & Natural & $39.22 \pm 6.46$ & b \\
\hline Low & Artificial & $43.76 \pm 8.04$ & b \\
\hline High & Natural & $23.86 \pm 6.48$ & c \\
\hline High & Artificial & $24.79 \pm 5.48$ & c \\
\hline
\end{tabular}

Table 3. Predator avoidance behaviour $(\mathrm{PAB})$ values (mean $\pm 1 \mathrm{SE})$ under five different experimental treatments of habitat complexity and material used to create structure. Tukey-Kramer designations show results of post hoc analysis of the two-way ANOVA to show where differences between treatments occur.

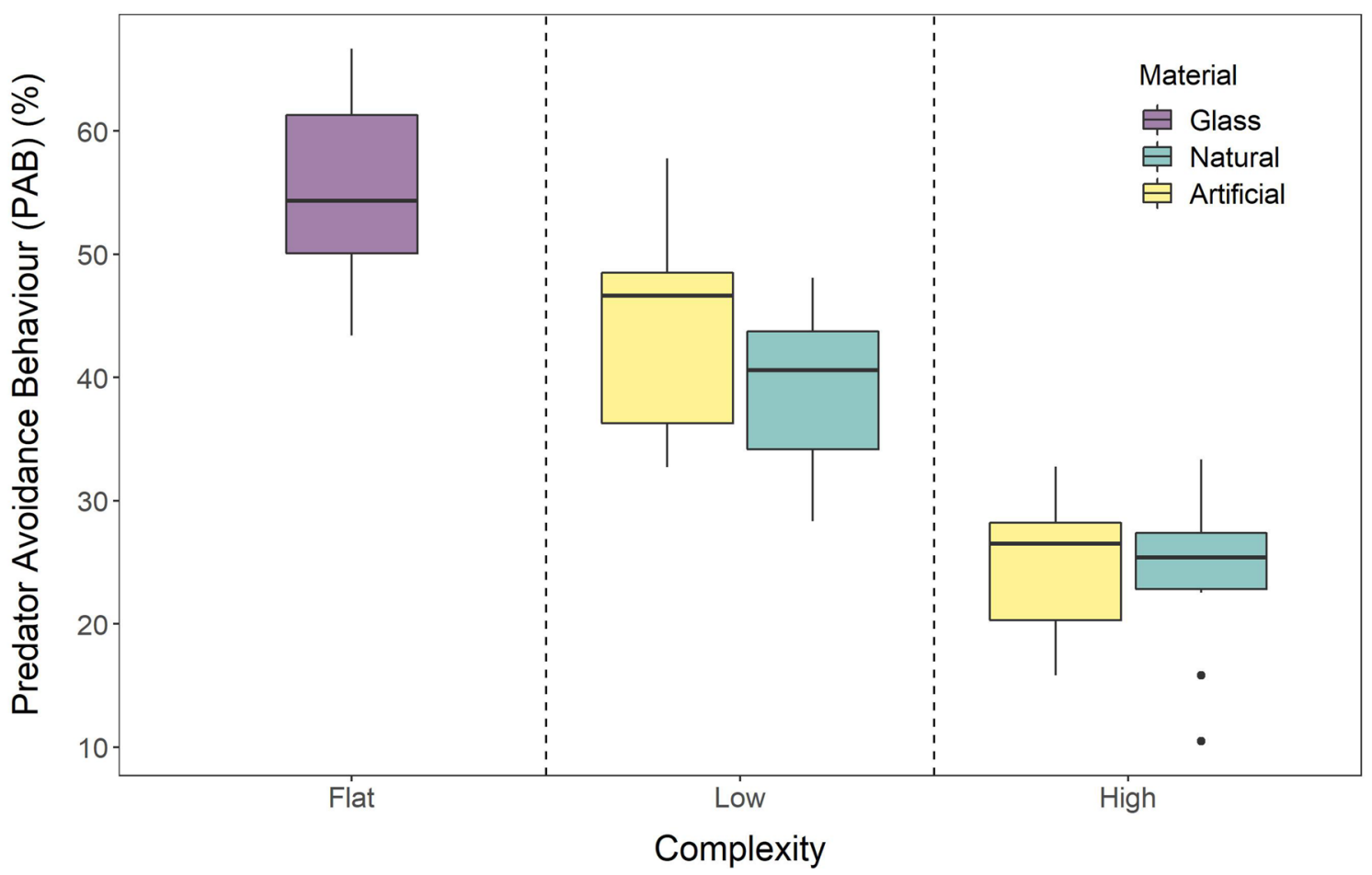

Figure 5. Impacts of habitat complexity on the predator avoidance behaviour (PAB) of D. antillarum. Flat treatments were carried out in trial tanks without any structure, low complexity treatments with natural material occurred in tanks enriched with fragments of reef rubble, and low complexity treatments with artificial materials were conducted in tanks with fragmented breezeblocks. High complexity treatments with natural material used reef rubble to simulate a reef crevice, and during high complexity treatments with artificial material individuals were provided with a whole breezeblock. The study was fully factorial and $n=10$ for each treatment. The bold horizontal line on each boxplot represents the mean, the box itself shows the interquartile range and the whiskers delimit the full range of the data. Letters above the plots show the result of a post hoc Tukey-Kramer analysis and show where significant differences between treatments occur.

$\left(F_{2,45}=13.52, p=2.52^{-5}\right)$ have a significant effect on the magnitude of $D$. antillarum PAB. However, post hoc Tukey-Kramer analysis revealed that material did not have an effect within the complexity treatments (Table 3).

In the control treatment, where responses were tested in an unenriched tank with a glass bottom, mean PAB was $54.94 \pm 7.64 \%$. On average, PAB was reduced by $24 \%$ when the tank was enriched with a low complexity environment (natural material $=39.22 \pm 6.46 \%$; artificial material $=43.76 \pm 8.04$ ), and by $52 \%$ when it was enriched with a high complexity environment (natural material $=23.86 \pm 6.48 \%$; artificial material $=24.79 \pm 5.48 \%$ ) (Fig. 5).

Impacts of artificial reefs on $D$. antillarum population density. At the start of this study, the degraded reefs of La Ensenada exhibited fractal dimension of the ecologically relevant $5-15 \mathrm{~cm}$ spatial range $\left(\mathrm{D}_{5-15}\right)$ of $2.08 \pm 0.01$. This compared to $2.14 \pm 0.01$ for Utila's reefs without urchins, and $2.22 \pm 0.04$ for Utila's reefs with urchins. With the addition of our artificial reefs, this complexity was increased to $2.16 \pm 0.00$ (Fig. 2). Fractal dimension (D) used as a proxy for 3D structure gives a value between 2 (perfect 2-dimensional surface) to 3 (perfect 3-dimensional surface) therefore the 2.08 to 2.16 increase associated with the deployment of the artificial reefs represents a $100 \%$ increase in habitat complexity. 


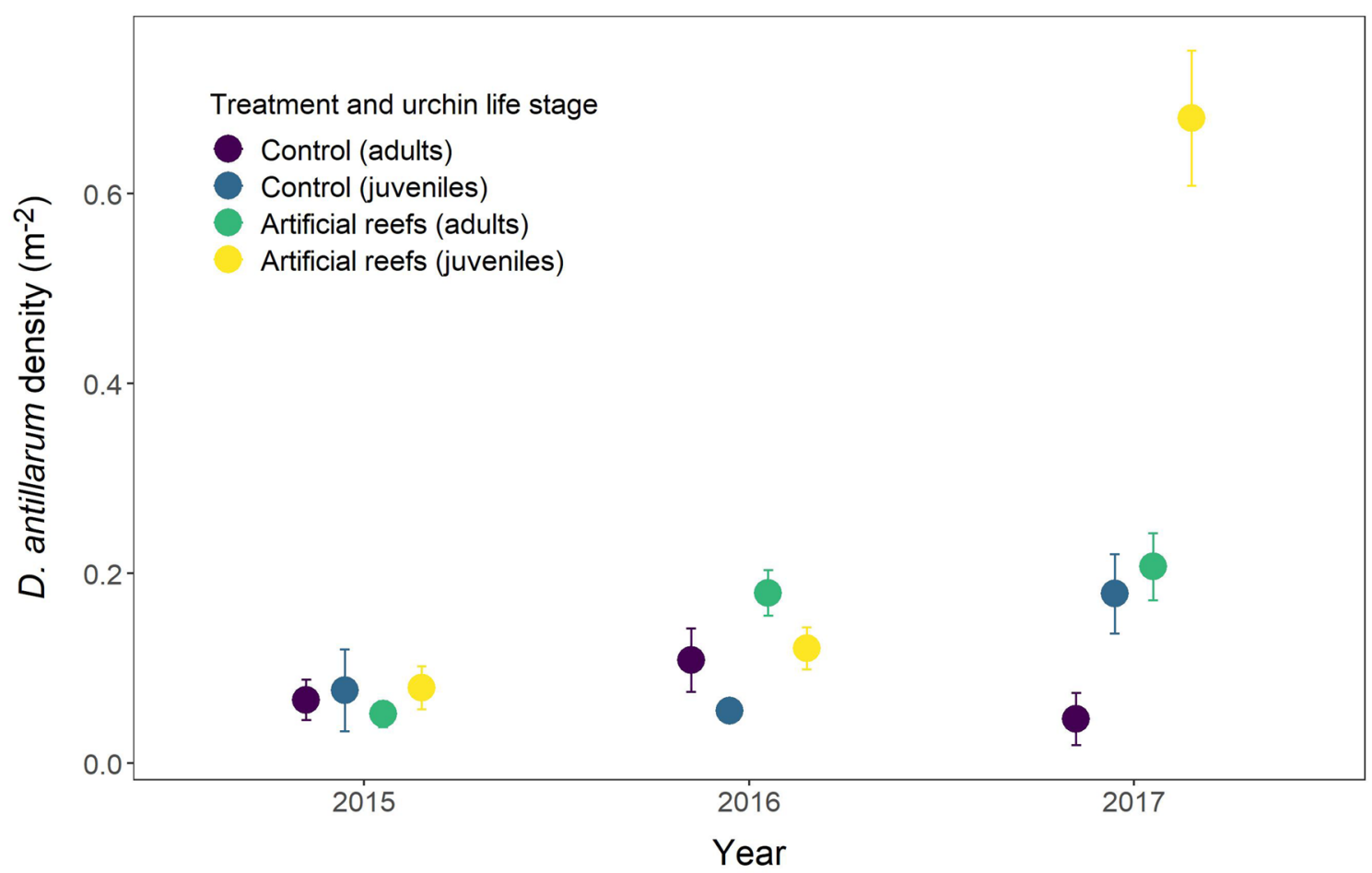

Figure 6. Temporal changes in the density of adult and juvenile D. antillarum on small artificial reef structures and nearby control reefs. Data were collected at the same time each year, but points are jittered to aid visualisation. Data shown are mean $\pm \mathrm{SE}$.

\begin{tabular}{|c|c|c|c|c|c|}
\hline & 2015 & 2016 & 2017 & $X_{2}$ & $p$ \\
\hline \multicolumn{6}{|l|}{ Control reefs } \\
\hline Adult urchins $\left(\mathrm{m}^{-2}\right)$ & $0.07(0.02)$ & $0.11(0.03)$ & $0.05(0.03)$ & 0.22 & 0.64 \\
\hline Juvenile urchins $\left(\mathrm{m}^{-2}\right)$ & $0.08(0.04)$ & $0.06(0.01)$ & $0.18(0.04)$ & 4.54 & 0.05 \\
\hline Total urchins $\left(\mathrm{m}^{-2}\right)$ & $0.14(0.06)$ & $0.16(0.04)$ & $0.23(0.05)$ & 1.46 & 0.24 \\
\hline Macroalgae cover (\%) & $21.58(0.50)$ & $23.00(2.53)$ & $21.42(2.36)$ & 0.003 & 0.95 \\
\hline Coral recruits $\left(\mathrm{m}^{-2}\right)$ & $3.38(0.28)$ & $1.67(0.22)$ & $0.87(0.15)$ & 70.06 & $<0.05$ \\
\hline \multicolumn{6}{|l|}{ Artificial reefs (ARs) } \\
\hline Adult urchins $\left(\mathrm{m}^{-2}\right)$ & $0.05(0.01)$ & $0.18(0.02)$ & $0.21(0.04)$ & 25.82 & $<0.05$ \\
\hline Juvenile urchins $\left(\mathrm{m}^{-2}\right)$ & $0.08(0.02)$ & $0.12(0.02)$ & $0.68(0.07)$ & 119.08 & $<0.05$ \\
\hline Total urchins $\left(\mathrm{m}^{-2}\right)$ & $0.13(0.03)$ & $0.30(0.04)$ & $0.89(0.08)$ & 85.01 & $<0.05$ \\
\hline Macroalgae cover (\%) & $56.07(1.19)$ & $52.92(1.04)$ & $38.13(0.91)$ & 74.19 & $<0.05$ \\
\hline Coral recruits $\left(\mathrm{m}^{-2}\right)$ & $4.32(0.19)$ & $3.47(0.29)$ & $4.01(0.20)$ & 4.38 & $<0.05$ \\
\hline
\end{tabular}

Table 4. Mean (SE) values of $D$. antillarum population densities (individuals $\mathrm{m}^{-2}$ ), macroalgal benthic cover (\%) and juvenile coral recruit densities (individuals $\mathrm{m}^{-2}$ ) for control and artificial reefs in La Ensenada surveyed in 2015, 2016, and 2017. Also shown are the results of Friedman tests comparing years.

Prior to the deployment of ARs in 2015, control reefs in La Ensenada exhibited mean adult and juvenile $D$. antillarum densities of $0.07 \pm 0.02 \mathrm{~m}^{-2}$ and $0.08 \pm 0.04 \mathrm{~m}^{-2}$ respectively. There was no significant increase in adult D. antillarum population density over the study period $\left(2016=0.11 \pm 0.03 \mathrm{~m}^{-2} ; 2017=0.05 \pm 0.03 \mathrm{~m}^{-2} ; F_{2}=0.22\right.$, $p=0.64$ ) (Fig. 6). However, whilst the juvenile D. antillarum population remained stable between 2015 and 2016, it had more than doubled by 2017 relative to the first time point $\left(2016=0.06 \pm 0.01 \mathrm{~m}^{-2} ; 2017=0.18 \pm 0.04 \mathrm{~m}^{-2}\right.$; $\left.F_{2}=4.54, p=0.05\right)$ (Table 4).

Within a $5 \mathrm{~m}$ radius of the ARs, adult $D$. antillarum densities increased by $260 \%$ between $2015\left(0.05 \pm 0.01 \mathrm{~m}^{-2}\right)$ and $2016\left(0.18 \pm 0.02 \mathrm{~m}^{-2}\right)$, and by a further $17 \%$ to $0.21 \pm 0.04 \mathrm{~m}^{-2}$ in $2017\left(X_{2}=21.20, p=2.49 \times 10^{-5}\right)$ (Fig. 6). Changes in juvenile populations in the first year mirrored those of their adult counterparts $(0.08 \pm 0.02$ to $0.12 \pm 0.02 \mathrm{~m}^{-2}$ ), but a six-fold increase in density observed in the second year (to $0.679 \pm 0.07 \mathrm{~m}^{-2}$ ) indicates a significant increase in the rate of recruitment $\left(X_{2}=116.15, p<2.2 \times 10^{-16}\right)$ (Table 4$)$. 
Benthic community changes on artificial reefs. Prior to AR deployment, control reefs exhibited mean macroalgae cover of $21.58 \pm 0.50 \%$ and juvenile coral recruit densities of $3.38 \pm 0.69 \mathrm{~m}^{-2}$ (Table 4 ). They showed no subsequent significant change in macroalgae cover over the course of this study, but the abundance of juvenile coral recruits decreased by $50 \%$ in the first year, and a further $47 \%$ in the second year $\left(X_{2}=12.00, p=0.002\right)$.

By contrast, within a $5 \mathrm{~m}$ radius of the ARs, macroalgae cover decreased from $56.07 \pm 1.19$ to $52.92 \pm 1.04 \%$ in the first year, and again to $38.13 \pm 0.91 \%$ in the second year $\left(X^{2}=122.88, p<2.2 \times 10^{-16}\right)$ representing a $17.94 \%$ reduction in actual percentage cover (Table 4). There was no significant change in the abundance of coral recruits throughout this time period, despite the significant decline on nearby control reefs.

\section{Discussion}

Numerous correlative studies have suggested that $D$. antillarum populations are failing to recover because processes of reef flattening ${ }^{8,39}$ have reduced complexity creating a deficit of suitable habitat that leaves individuals vulnerable to predation ${ }^{28,70}$. The photogrammetric and lab-based data presented here provide experimental evidence to support this assertion. Fractal dimension analysis of 3D models ${ }^{55}$ demonstrates that $D$. antillarum preferentially inhabit areas of higher complexity (D) at ecologically relevant spatial scales. This indicates the existence of either an active preference for complexity, supported by studies showing that individuals compete for shelter even in the absence of a predation threat ${ }^{71}$, and/or a passive fitness benefit that allows recruits to mature beyond their predator escape size and therefore survive into adulthood ${ }^{72,73}$.

The importance of predation as a driver of $D$. antillarum population dynamics has been demonstrated experimentally in Puerto Rico, where the removal of the predatory wrasse species Thalassoma bifasciatum and Halichoeres bivittatus allowed significant population expansion ${ }^{74}$. This finding, coupled with the reduction in PAB associated with increasing structural complexity observed in the lab-based behaviour study, provides further evidence that the likely mechanism driving the high habitat complexity preference is the protection that complex habitats afford against predation. $\mathrm{PAB}$ is an important survival reflex, but it has a high energetic requirement and is therefore likely to be reduced in any scenario where the survival benefits do not outweigh the costs ${ }^{48,59,60}$, i.e. in a complex habitat where the defensive role of PAB is, at least partially, fulfilled by the individual's environment.

As population densities increase, $D$. antillarum aggregate and form protective spine canopies ${ }^{57}$ which makes them less reliant on shelter for survival ${ }^{75}$; reliance on PAB is presumably also reduced. The importance of the interaction between habitat structure and predation as a driver of $D$. antillarum population dynamics is therefore likely to be greater in contemporary low-density populations than it was in historically high-density populations. Population restoration through provision of artificial shelter may therefore stimulate a positive feedback loop that ultimately reduces reliance on habitat structure and PAB. Artificial structures may protect individuals against predators, whilst also reducing reliance on $\mathrm{PAB}$ thus allowing more resources to be allocated to reproduction. These effects may operate synergistically to increase population density and allow the formation of a spine canopy, which would replace shelter and PAB to become the major mechanism of predatory defence. The low-habitat-complexity barrier to $D$. antillarum population recovery ${ }^{28}$ may be overcome.

It is also suggested that $D$. antillarum populations are failing to recover because they are asynchronous spawners ${ }^{26,41,42}$, which means they are unable to overcome the Allee effect that was established after their massmortality. This barrier is likely exacerbated by the loss of habitat that accompanied the functional extinction of $D$. antillarum ${ }^{38}$, as it increased nearest-neighbour distances and reduced the probability of fertilisation ${ }^{40}$. The significant $\mathrm{PAB}$ reduction observed in the high complexity treatment relative to the low complexity and flat treatments in the lab-based study may represent a large energy saving which allows individuals to allocate resources to reproduction rather than predatory defence ${ }^{59}$. Artificial reefs may therefore stimulate $D$. antillarum population recovery not only by reducing vulnerability to predation, but also by decreasing nearest-neighbour distances and increasing resource allocation to reproduction, both of which will help overcome the Allee effect that contributes to their continued suppression.

Data presented from the artificial reef (AR) study show that augmentation of habitat structure can stimulate increases in $D$. antillarum population density, and differences in the pattern of recovery between adults and juveniles corroborate the findings of earlier studie ${ }^{26,40-42}$ by indicating that adult densities must increase before juvenile recruitment can occur. The negative relationship between $D$. antillarum population density and macroalgae ${ }^{15,21,22}$ and the positive relationship between population density and juvenile coral recruits ${ }^{76-78}$ is well documented. It is therefore perhaps unsurprising, that our ecological surveys suggested that the colonisation of ARs by $D$. antillarum over the 24 -months of this study stimulated both a significant decrease in macroalgae cover compared to adjacent control reefs, and maintained stable juvenile coral recruit densities against a backdrop of declining densities on control reefs. A longer time series would be needed to determine whether these initial benefits translate into longer-term increases in mature scleractinian coral cover.

The successes of $D$. antillarum restoration initiatives have been variable, but several studies in the Florida Keys and Jamaica have found that the ecological benefits can be profound $d^{50,77,79}$. A study that attempted to restock populations to mean densities of 4 individuals $\mathrm{m}^{-2}$ found that populations 'relaxed' to 1 individual $\mathrm{m}^{-2}$, and the high mortality was attributed to predation on reintroduced juveniles due to a lack of 3D structure on the reef ${ }^{19}$. This highlights that for reintroduction to be successful, the factor(s) preventing recovery must first be removed. The findings we present here suggest that the augmentation of structural complexity that accompanies the deployment of ARs may mitigate a major barrier to population recovery and increase the success of $D$. antillarum reintroduction initiatives, leading to improvements in reef health.

The three lines of experimental evidence presented here add weight to the previous assertion that habitat structure plays a key role in regulating $D$. antillarum population dynamics by creating predation refugia, and decreasing nearest-neighbour distances to increase the probability of fertilisation success ${ }^{40,42}$. Provision of artificial habitat complexity targeted towards the species-specific requirements of D. antillarum may stimulate 
population recovery on contemporary Caribbean coral reefs and reinstate the lost ecological functions they historically fulfilled to stimulate benthic recovery on degraded reefs.

Received: 22 September 2020; Accepted: 25 March 2021

Published online: 30 April 2021

\section{References}

1. Hughes, T. P. et al. Coral reefs in the Anthropocene. Nature 546, 82-90 (2017)

2. de Groot, R. et al. Global estimates of the value of ecosystems and their services in monetary units. Ecosyst. Serv. 1, 50-61 (2012).

3. Exton, D. A. et al. Artisanal fish fences pose broad and unexpected threats to the tropical coastal seascape. Nat. Commun. 10, 2100 (2019).

4. Pandolfi, J. M. et al. Global trajectories of the long-term decline of coral reef ecosystems. Science (80-) 301, 955-958 (2003).

5. Graham, N. A. J., Jennings, S., MacNeil, M. A., Mouillot, D. \& Wilson, S. K. Predicting climate-driven regime shifts versus rebound potential in coral reefs. Nature 518, 94-97 (2015).

6. Roff, G. \& Mumby, P. J. Global disparity in the resilience of coral reefs. Trends Ecol. Evol. 27, 404-413 (2012).

7. Jackson, J.B.C., Donovan, M.K., Cramer, K.L. and Lam, V.V. Status and trends of Caribbean coral reefs. Global Coral Reef MonitoringNetwork, IUCN, Gland, Switzerland, pp.1970-2012. (2014).

8. Alvarez-Filip, L., Dulvy, N. K., Gill, J. A., Côté, I. M. \& Watkinson, A. R. Flattening of Caribbean coral reefs: region-wide declines in architectural complexity. Proc. R. Soc. B Biol. Sci. 276, 3019-3025 (2009).

9. Elmqvist, T. et al. Response diversity, ecosystem change, and resilience. Front. Ecol. Environ. 1, $488-494$ (2003).

10. Sasaki, T., Furukawa, T., Iwasaki, Y., Seto, M. \& Mori, A. S. Perspectives for ecosystem management based on ecosystem resilience and ecological thresholds against multiple and stochastic disturbances. Ecol. Ind. 57, 395-408 (2015).

11. McCann, K. S. The diversity-stability debate. Nature 405, 228-233 (2000).

12. Bellwood, D. R., Hughes, T. P., Folke, C. \& Nyström, M. Confronting the coral reef crisis. Nature 429, 827-833 (2004).

13. Mumby, P. J., Hastings, A. \& Edwards, H. J. Thresholds and the resilience of Caribbean coral reefs. Nature 450, 98-101 (2007).

14. Hughes, T. P., Graham, N. A. J., Jackson, J. B. C., Mumby, P. J. \& Steneck, R. S. Rising to the challenge of sustaining coral reef resilience. Trends Ecol. Evol. 25, 633-642 (2010).

15. Solandt, J. L. \& Campbell, A. C. Macroalgal feeding characteristics of the sea urchin Diadema antillarum Philippi at Discovery Bay, Jamaica. Caribb. J. Sci. 37, 227-238 (2001).

16. Chiappone, M., Rutten, L. M., Miller, S. L. \& Swanson, D. W. Recent trends (1999-2011) in population density and size of the echinoid Diadema antillarum in the Florida Keys. Florida Sci. 76, 23-35 (2013).

17. Lessios, H. A. The great Diadema antillarum die-off: 30 years later. Annu. Rev. Mar. Sci. 8, 267-283 (2016).

18. Bruno, J. F., Sweatman, H., Precht, W. F., Selig, E. R. \& Schutte, V. G. W. Assessing evidence of phase shifts from coral to macroalgal dominance on coral reefs. Ecol. Soc. Am. 90, 1478-1484 (2009).

19 Miller, M. W., Szmant, A. M. \& Precht, W. F. Lessons learned from experimental key-species restoration. In Coral Reef Restoration Handbook, 219-234 (ed. Precht, W. F.) (Taylor \& Francis, 2006).

20. Mumby, P. J., Hedley, J. D., Zychaluk, K., Harborne, A. R. \& Blackwell, P. G. Revisiting the catastrophic die-off of the urchin Diadema antillarum on Caribbean coral reefs: fresh insights on resilience from a simulation model. Ecol. Modell. 196, 131-148 (2006).

21. Myhre, S. \& Acevedo-Gutiérrez, A. Recovery of sea urchin Diadema antillarum populations is correlated to increased coral and reduced macroalgal cover. Mar. Ecol. Prog. Ser. 329, 205-210 (2007).

22. Carpenter, R. C. Predator and population density control of homing behavior in the Caribbean echinoid Diadema antillarum. Mar. Biol. 82, 101-108 (1984).

23. Edmunds, P. J. \& Carpenter, R. C. Recovery of Diadema antillarum reduces macroalgal cover and increases abundance of juvenile corals on a Caribbean reef. Proc. Natl. Acad. Sci. U. S. A. 98, 5067-5071 (2001).

24. Wanders, J. B. W. The role of benthic algae in the shallow reef of Curaçao (Netherlands Antilles) III: the significance of grazing. Aquat. Bot. 3, 357-390 (1977).

25. Bak, R. P. M., Carpay, M. J. E. \& de Ruyter van Steveninck, E. D. Densities of the sea urchin Diadema antillarum before and after mass mortalities on the coral reefs of Curacao. Mar. Ecol. Prog. Ser. 17, 105-108 (1984).

26. Levitan, D. R. Algal-urchin biomass responses following mass mortality of Diadema antillarum Philippi at Saint John, U.S. Virgin Islands. J. Exp. Mar. Biol. Ecol. 119, 167-178 (1988).

27. Chiappone, M., Rutten, L., Swanson, D. \& Miller, S. Population status of the urchin Diadema antillarum in the Florida Keys 25 years after the Caribbean mass mortality. In Proceedings of 11th International Coral Reef Symposium 706-710 (2008).

28. Bodmer, M. D. V., Rogers, A., Speight, M. R., Lubbock, N. \& Exton, D. A. Using an isolated population boom to explore barriers to recovery in the keystone Caribbean coral reef herbivore Diadema antillarum. Coral Reefs 34, 1011-1021 (2015).

29. Lessios, H. A., Robertson, D. R. \& Cubit, J. D. Spread of Diadema mass mortality through the Caribbean. Science (80-) 226, 335-337 (1984).

30. Liddell, W. D. \& Ohlhorst, S. L. Changes in benthic community composition following the mass mortality of Diadema at Jamaica. J. Exp. Mar. Biol. Ecol. 95, 271-278 (1986).

31. Betchel, J. D., Gayle, P. \& Kaufman, L. The return of Diadema antillarum to Discovery Bay: patterns of distribution and abundance. In Proceedings of 10th International Coral Reef Symposium 367-375 (2006).

32. Robertson, D. R. Increases in surgeonfish populations after mass mortality of the sea urchin Diadema antillarum in Panamá indicate food limitation. Mar. Biol. 111, 437-444 (1991).

33. Lessios, H. A. Diadema antillarum populations in Panama 20 years following mass mortality. Coral Reefs 24, 125-127 (2005).

34. Hunte, W. \& Younglao, D. Recruitment and population recovery of Diadema antillarum (Echinodermata; Echinoidea) in Barbados. Mar. Ecol. Prog. Ser. 45, 109-119 (1988).

35. Noriega, N., Pauls, S. M. \& del Mónaco, C. Abundancia de Diadema antillarum (Echinodermata: Echinoidea) en las costas de Venezuela. Rev. Biol. Trop. 54, 793-802 (2006).

36. Debrot, A. O. \& Nagelkerken, I. Recovery of the long-spined sea urchin Diadema antillarum in Curacao (Netherlands Antilles) linked to lagoonal and wave sheltered shallow rocky habitats. Bull. Mar. Sci. 72, 415-424 (2006).

37. Vermeij, M. J. A., Debrot, A. O., van der Hal, N., Bakker, J. \& Bak, R. P. M. Increased recruitment rates indicate recovering populations of the sea urchin Diadema antillarum on Curaçao. Bull. Mar. Sci. 86, 719-725 (2010).

38. Carpenter, K. E. et al. One-third of reef-building corals face elevated extinction risk from climate change and local impacts. Science (80-) 321, 560-563 (2008).

39. Gardner, T. A., Côté, I. M., Gill, J. A., Grant, A. \& Watkinson, A. R. Long-term region-wide declines in Caribbean corals. Science (80-) 301, 958-960 (2003).

40. Pennington, J. T. The ecology of fertilization of echinoid eggs: the consequences of sperm dilution, adult aggregation, and synchronous spawning. Biol. Bull. 169, 417-430 (1985).

41. Levitan, D. R. Influence of body size and population density on fertilization success and reproductive output in a free-spawning invertebrate. Biol. Bull. 181, 261-268 (1991). 
42. Levitan, D. R., Edmunds, P. J. \& Levitan, K. E. What makes a species common? No evidence of density-dependent recruitment or mortality of the sea urchin Diadema antillarum after the 1983-1984 mass mortality. Oecologia 175, 117-128 (2014).

43. Lacey, E. A., Fourqurean, J. W. \& Collado-Vides, L. Increased algal dominance despite presence of Diadema antillarum populations on a Caribbean coral reef. Bull. Mar. Sci. 89, 603-620 (2013).

44. Dumas, P., Kulbicki, M., Chifflet, S., Fichez, R. \& Ferraris, J. Environmental factors influencing urchin spatial distributions on disturbed coral reefs (New Caledonia, South Pacific). J. Exp. Mar. Biol. Ecol. 344, 88-100 (2007).

45. Rogers, A. \& Lorenzen, K. Does slow and variable recovery of Diadema antillarum on Caribbean fore-reefs reflect densitydependent habitat selection? Front. Mar. Sci. 3, 63 (2016).

46. Alvarado, J. J., Cortés, J., Guzman, H. \& Reyes-Bonilla, H. Density, size, and biomass of Diadema mexicanum (Echinoidea) in Eastern Tropical Pacific coral reefs. Aquat. Biol. 24, 151-161 (2016).

47. Ogden, J. C. \& Carpenter, R. C. Long-spined black sea urchin. Biol. Rep. 82, 1-17 (1987).

48. Bodmer, M. D. V. et al. Interacting effects of temperature, habitat and phenotype on predator avoidance behaviour in Diadema antillarum: implications for restorative conservation. Mar. Ecol. Prog. Ser. 566, 105-115 (2017).

49. Andradi-Brown, D. A., Gress, E., Wright, G., Exton, D. A. \& Rogers, A. D. Reef fish community biomass and trophic structure changes across shallow to upper-mesophotic reefs in the mesoamerican barrier reef, Caribbean. PLoS ONE 11, 1-19 (2016).

50. Rodríguez-Barreras, R., Pérez, M. E., Mercado-Molina, A. E. \& Sabat, A. M. Arrested recovery of Diadema antillarum population: survival or recruitment limitation? Estuar. Coast. Shelf Sci. 163, 167-174 (2015).

51. Risk, M. J. Fish diversity on a coral reef in the Virgin Islands. Atoll Res. Bull. 153, 1-4 (1972).

52. Figueira, W. et al. Accuracy and precision of habitat structural complexity metrics derived from underwater photogrammetry. Remote Sens. 7, 16883-16900 (2015).

53. Leon, J. X., Roelfsema, C. M., Saunders, M. I. \& Phinn, S. R. Measuring coral reef terrain roughness using 'Structure-from-Motion' close-range photogrammetry. Geomorphology 242, 21-28 (2015).

54. Storlazzi, C. D., Dartnell, P., Hatcher, G. A. \& Gibbs, A. E. End of the chain? Rugosity and fine-scale bathymetry from existing underwater digital imagery using structure-from-motion (SfM) technology. Coral Reefs 35, 889-894 (2016).

55. Young, G. C., Dey, S., Rogers, A. D. \& Exton, D. A. Cost and time-effective method for multiscale measures of rugosity, fractal dimension, and vector dispersion from coral reef 3D models. PLoS ONE 12, e0175341 (2017).

56. Zawada, D. G. \& Brock, J. C. A multiscale analysis of coral reef topographic complexity using lidar-derived bathymetry. J. Coast. Res. 2009, 6-16 (2009).

57. Randall, J. E., Schroeder, R. E. \& Starck, W. A. Notes on the biology of the echinoid Diadema antillarum. Caribb. J. Sci. 4, 421-433 (1964).

58. Hunt, C. L. et al. Aggregating behaviour in invasive Caribbean lionfish is driven by habitat complexity. Sci. Rep. 9, 783 (2019).

59. Millott, N. \& Yoshida, M. The shadow reaction of Diadema antillarum Philippi I: the spine response and its relation to the stimulus. J. Exp. Biol. 37, 363-375 (1960).

60. Millott, N. \& Yoshida, M. The shadow reaction of Diadema antillarum Philippi II: inhibition by light. J. Exp. Biol. 37, 376-389 (1960).

61. Raible, F. et al. Opsins and clusters of sensory G-protein-coupled receptors in the sea urchin genome. Dev. Biol. 300, 461-475 (2006).

62. Ullrich-Lüter, E. M., D’Aniello, S. \& Arnone, M. I. C-opsin expressing photoreceptors in echinoderms. Integr. Comp. Biol. 53, 27-38 (2013).

63. Yoshida, M. On the light response of the chromatophore of the sea-urchin, Diadema setosum (Leske). J. Exp. Biol. 33, 119-123 (1956).

64. JPL MUR MEaSUREs. GHRSST Level 4 MUR global foundation sea surface temperature analysis. Version 4.1 PO.DAAC, CA, USA. Dataset accessed 23 Jan 2021 at https://doi.org/10.5067/GHGMR-4FJ04 (2015).

65. Pickering, H., Whitmarsh, D. \& Jensen, A. Artificial reefs as a tool to aid rehabilitation of coastal ecosystems: investigating the potential. Mar. Pollut. Bull. 37, 505-514 (1999).

66. Fitzhardinge, R. C. \& Bailey-Brock, J. H. Colonization of artificial reef materials by corals and other sessile organisms. Bull. Mar. Sci. 44, 567-579 (1989).

67. R Core Team. R: A Language and Environment for Statistical Computing. Vienna. https://www.r-project.org/. (2016).

68. RStudio Team. RStudio: Integrated Development for $R$ (2015).

69. Dinno, A. conover.test: Conover-Iman test of multiple comparisons using rank sums. R Package Version 1.1.5. (2017).

70. Scheibling, R. E. \& Robinson, M. C. Settlement behaviour and early post-settlement predation of the sea urchin Strongylocentrotus droebachiensis. J. Exp. Mar. Biol. Ecol. 365, 59-66 (2008).

71. Kintzing, M. D. \& Butler, M. J. The influence of shelter, conspecifics, and threat of predation on the behavior of the long-spined sea urchin (Diadema antillarum). J. Shellfish Res. 33, 781-785 (2014).

72. Clemente, S., Hernández, J. C., Toledo, K. \& Brito, A. Predation upon Diadema aff. antillarum in barren grounds in the Canary Islands. Sci. Mar. 71, 745-754 (2007).

73. Jennings, L. B. \& Hunt, H. L. Settlement, recruitment and potential predators and competitors of juvenile echinoderms in the rocky subtidal zone. Mar. Biol. 157, 307-316 (2010).

74. Rodríguez-Barreras, R. Demographic implications of predatory wrasses on low-density Diadema antillarum populations. Mar. Biol. Res. 14, 383-391 (2018).

75. Delgado, G. A. \& Sharp, W. C. Does artificial shelter have a place in Diadema antillarum restoration in the Florida Keys? Tests of habitat manipulation and sheltering behavior. Glob. Ecol. Conserv. 26, e01502 (2021).

76. Sammarco, P. W. \& Williams, A. H. Damselfish territoriality: influence on Diadema antillarum distribution and implications for coral community structure. Mar. Ecol. Prog. Ser. 8, 53-59 (1982).

77. Nedimyer, K. \& Moe, M. A. 2003. Techniques development for the reestablishment of the long-spined sea urchin, Diadema antillarum, on two small patch reefs in the upper Florida Keys. 2002-2003 Sanctuary Science Report: An Ecosystem Report Card After Five Years of Marine Zoning.

78. Idjadi, J., Haring, R. \& Precht, W. Recovery of the sea urchin Diadema antillarum promotes scleractinian coral growth and survivorship on shallow Jamaican reefs. Mar. Ecol. Prog. Ser. 403, 91-100 (2010).

79. Macia, S., Robinson, M. P. \& Nalevanko, A. Experimental dispersal of recovering Diadema antillarum increases grazing intensity and reduces macroalgal abundance on a coral reef. Mar. Ecol. Prog. Ser. 348, 173-182 (2007).

\section{Acknowledgements}

We would like to thank all the Operation Wallacea staff and volunteers who helped with data collection and logistical support for this project, and the Honduran Government's Instituto de Conservación Forestal (ICF) for permission to conduct this research. We also thank staff at Tela Marine Research Centre and Coral View Research Centre. This work was possible thanks to a $\mathrm{PhD}$ studentship to MB funded by Operation Wallacea. 


\section{Author contributions}

M.D.V.B., D.A.E., P.M.W. and P.A. conceived and designed the study, and the data were collected by M.D.V.B., S.E.C., S.H., W.C. Fieldwork support was provided by A.O.B. M.D.V.B. analysed the data, M.D.V.B. and D.A.E. wrote the manuscript and D.A.E. produced the figures. All authors reviewed drafts of the manuscript.

\section{Competing interests}

The authors declare no competing interests.

\section{Additional information}

Correspondence and requests for materials should be addressed to M.D.V.B. or S.H.

Reprints and permissions information is available at www.nature.com/reprints.

Publisher's note Springer Nature remains neutral with regard to jurisdictional claims in published maps and institutional affiliations.

(c) (i) Open Access This article is licensed under a Creative Commons Attribution 4.0 International License, which permits use, sharing, adaptation, distribution and reproduction in any medium or format, as long as you give appropriate credit to the original author(s) and the source, provide a link to the Creative Commons licence, and indicate if changes were made. The images or other third party material in this article are included in the article's Creative Commons licence, unless indicated otherwise in a credit line to the material. If material is not included in the article's Creative Commons licence and your intended use is not permitted by statutory regulation or exceeds the permitted use, you will need to obtain permission directly from the copyright holder. To view a copy of this licence, visit http://creativecommons.org/licenses/by/4.0/.

(C) The Author(s) 2021 